\title{
Effect of Cultivation Methods and Nitrogen Management Strategies on Growth and Yield of Rice (Oryza sativa L.) Grown in Coastal Alluvial Soils of Southern India
}

\author{
D. Dinesh ${ }^{1}$, A. Baskar ${ }^{2}$ and K. Rajan ${ }^{3}$ \\ ${ }^{1}$ Indian Council of Agricultural Research- Indian Institute of Soil and Water Conservation, \\ Research Centre, Vasad, Gujarat, India \\ ${ }^{2}$ Department of Soil Science and Agricultural Chemistry, PAJANCOA\&RI, Karaikal, Union \\ Territory of Puducherry, India \\ ${ }^{3}$ Indian Council of Agricultural Research- Indian Institute of Soil and Water Conservation, \\ Research Centre, Udhagamandalam, Tamil Nadu, India \\ *Corresponding author
}

\begin{tabular}{|c|c|}
\hline & A B S T R A C T \\
\hline & $\begin{array}{l}\text { A field experiment was conducted to investigate the methods of cultivation and } \\
\text { optimization of nitrogen requirement of rice crop in coastal alluvial soils, Karaikal, } \\
\text { Pondicherry, India. Experiment was laid out in a split plot design with methods of rice } \\
\text { cultivation as main plot treatment consisted of System of Rice Intensification (SRI), }\end{array}$ \\
\hline Keywords & Integrated Crop Management (ICM), Line Planting (LP) and Random Planting (RP) and \\
\hline $\begin{array}{l}\text { Rice; Nitrogen } \\
\text { management, } \\
\text { SRI, ICM, } \\
\text { grain yield. }\end{array}$ & $\begin{array}{l}\text { nitrogen managements strategies as subplot treatment consisted of without nitrogen as } \\
\text { control, blanket recommendation, LCC } 4 \text {, LCC } 5 \text {, SPAD } 35 \text { and SPAD } 37 \text {. The result } \\
\text { showed that Plant height and tiller count were improved by cultivation methods. LCC } 4 \\
\text { registered higher plant height, productive tillers number, longer and heavier panicles and }\end{array}$ \\
\hline Article Info & higher than SRI and RP respectively. Among nitrogen managements, LCC 4 recorded \\
\hline $\begin{array}{l}\text { Accepted: } \\
\text { 20 February } 2017 \\
\text { Available Online: } \\
10 \text { March } 2017\end{array}$ & $\begin{array}{l}\text { highest grain yield of } 2.66 \mathrm{t} \mathrm{ha}^{-1} \text { which was } 11.1,19.8,26.4 \text { and } 40.7 \% \text { higher than } \\
\text { blanket, SPAD } 35, \text { SPAD } 37 \text { and control respectively. ICM recorded significantly highest } \\
\text { straw yield }\left(5.49 \mathrm{t} \mathrm{ha}^{-1}\right) \text { which was the same as with SRI. The straw yield of ICM was } 28.4 \\
\text { and } 34.6 \% \text { higher than LP and RP respectively. Highest straw yield of } 5.88 \mathrm{tha}^{-1} \text { was }\end{array}$ \\
\hline & $\begin{array}{l}\text { observed with LCC } 5 \text { which was } 1.2,15.4,30.7,53.7 \text { and } 59.2 \% \text { higher than LCC } 4 \text {, } \\
\text { Blanket, SPAD } 35 \text {, SPAD } 37 \text { and control respectively. LP with LCC } 4 \text { was the superior } \\
\text { combination than other treatment combinations with respect to growth and yield attributes. } \\
\text { It was inferred that potential of SRI and ICM could be explored only when the soil quality } \\
\text { is good enough to support vigorous tillering. }\end{array}$ \\
\hline
\end{tabular}

\section{Introduction}

Rice is the principal staple food for 65 per cent of the population in India. Rice occupies an area of 44 million hectare with an average production of 90 million tonnes with productivity of 2.0 tonnes per hectare. The demand for rice is expected to rise due to increase in population (1.6\% year $\left.{ }^{-1}\right)$ plus increased per capita income. It is estimated that in the year 2025 the requirement of rice would be 140 million tonnes. At the same 
time the area under rice cultivation is expected to reduce to 40 million ha in the next 15-20 years (Shobharani et al., 2010). To sustain present food self-sufficiency and to meet future food requirements, India has to increase its rice productivity by 3 per cent per year (Thiyagarajan, 2007).

To enhance productivity of any crop needs an integrated approach on soil, plant, water and climatic factors in appropriate manner. Among management strategies, fertilizer management accounts for 50 per cent of yield gap (Randhawa and Velayutham, 1989), plant density by 42-45 per cent; land preparation, pest, disease and weed management by $15-20$ per cent; post harvest technologies by about 7-26 per cent (Duarisamy et al., 2001).

System of Rice Intensification (popularly known as SRI), an alternative methodology for traditional flooded rice cultivation, developed in the 1980s in Madagascar (Laulanie 1993), has been promoted in countries around the world for more than a decade as a set of agronomic management practices for enhancing yield (Kabir and Uphoff 2007; Namara et al., 2008; Senthilkumar et al. 2008). The agronomic changes involved in SRI includes, use of much younger seedlings, planting single seedlings in a square pattern with wide spacing, keeping the soil moist but not continuously flooded, applying increased quantity of organic manures and use of mechanical weeder that provides active aeration in topsoil. Yield of rice could be enhanced by 2 to 3 times in SRI method (Uphoff, 2002) and up to $1.5 \mathrm{t} \mathrm{ha}^{-1}$ by ICM (Balasubramanian et al., 2004) by enhancing tillering phase, root penetration and nutrient assimilation. Predicting $\mathrm{N}$ requirement during crop growth period in actual quantity is a difficult and challenging task. In recent times, innovative tools like Soil and Plant Analysis Department meter (SPAD meter) and Leaf
Colour Chart (LCC) are employed to regulate $\mathrm{N}$ supply for rice crop. The SRI and ICM require precise $\mathrm{N}$ management to exploit maximum benefit. Appropriate method of cultivation and nitrogen management strategy and their combination could perform better than conventional practices. Keeping these in view, the present study investigates the effect of different methods of cultivation and $\mathrm{N}$ management strategies on growth, yield and yield attributes of rice crop.

\section{Materials and Methods}

The experiment was conducted at research farm of Pandit Jawaharlal Nehru College of Agriculture and Research Institute, Karaikal, Union Territory of Puducherry, India. The site was $12 \mathrm{kms}$ away from Bay of Bengal, geopositioned between $10^{\circ} 49^{\prime}$ North latitude and $78^{\circ} 43^{\prime}$ East longitude and 4 meters above Mean Sea Level. This region is in $11^{\text {th }}$ agroclimatic zone of India, classified as PC2coastal deltaic alluvial plain zone, under tropical climate with average annual rainfall of $1437 \mathrm{~mm}$ with 56 rainy days. Soil samples were collected from $0-15 \mathrm{~cm}$ depth and the initial soil characteristics were assessed with standard procedures which are furnished in Table 1. The soil is sandy-clay-loam, classified as Fluventic Haplustept (Coastal alluvium). Regarding available nutrient status of experimental sites, the available $\mathrm{N}$ is low, available $\mathrm{P}$ is high and available $\mathrm{K}$ is medium in status. Soil of the study area is saline-sodic.

The experiment was conducted in Split Plot Design (SPD) with the four methods of rice cultivation in main plots and six nitrogen management strategies with two replications. The rice variety ADT-43 of 115 days duration was the test crop. All the 48 plots were surrounded by $0.5 \mathrm{~m}$ wide bund to prevent lateral water movement and nutrient diffusion between plots. 
Seedlings raised in dapog nursery for SRI $\left(\mathrm{M}_{1}\right)$, modified mat nursery for ICM $\left(\mathrm{M}_{2}\right)$, and conventional nursery for LP (M3), and RP $\left(\mathrm{M}_{4}\right)$, were transplanted at $19^{\text {th }}$ Days after Sowing (DAS). In case of nitrogen management strategies, without nitrogen (as control) was $\mathrm{N}_{1}$ and blanket recommendation of $120 \mathrm{~kg} \mathrm{~N} \mathrm{ha}^{-1}$ was $\mathrm{N}_{2}$. The leaf colour chart (LCC) developed by Furuya (1987) in Japan was used for the treatment of $\mathrm{N}_{3}$ and $\mathrm{N}_{4}$ for deciding time of nitrogen application (top dressing). The LCC, which contain six strips of green colour starting from yellowish green shade (Critical value 1) to dark green shades (critical value 6), compared with growing paddy leaves and used as index of $\mathrm{N}$ demand by the crop. Darkness of green shade in LCC increases with increase of critical value. The measurements were taken at 10.00 a.m. by selecting the fully grown $3^{\text {rd }}$ leaf from the top and placing it on the LCC strips, in order to compare the match of colour of leaf with LCC strips. The readings were taken in ten randomly selected plants and then averaged. When the mean value fell below critical value of 4 and 5 in treatments of $\mathrm{N}_{3}$ and $\mathrm{N}_{4}$ respectively, nitrogen was top-dressed at the rate of $30 \mathrm{~kg} \mathrm{ha}^{-1}$ starting from 14 DAT to 70 DAT at weekly intervals. In the case of treatment $\mathrm{N}_{5}$ and $\mathrm{N}_{6}$, SPAD meter was used for $\mathrm{N}$ management where the measurements were made from 14 DAT up to 70 DAT at weekly intervals by measuring the colour intensity of the leaf. In this method, the fully expanded leaf was chosen and the leaf blade is fed into the SPAD meter (either one side of the midrib of the leaf). However, in the early stage of crop growth, the midrib might have not developed fully, hence, the entire leaf may be considered for the measurement. By adopting the above said procedure, twenty five readings were taken from each plot at random and then mean value worked out. The measurements were taken at 10.00 AM same day of every week and care was taken to avoid falling of direct sunlight on the leaf during measurement. When the mean value fell below the threshold value of 35 for $\mathrm{N}_{5}$ and 37 for $\mathrm{N}_{6}, 30 \mathrm{~kg} \mathrm{~N} \mathrm{ha}^{-1}$ was top-dressed from early stage to maximum tillering stage, $45 \mathrm{~kg} \mathrm{~N} \mathrm{ha}{ }^{-1}$ from maximum tillering to panicle initiation stage and $30 \mathrm{~kg} \mathrm{~N} \mathrm{ha}^{-1}$ from panicle initiation to flowering stage of crop growth (Babu et al., 2000).

With respect to source of nutrients, nitrogen was applied as urea in all the treatments. Phosphorus as Single Super Phosphate, Potassium as Muriate of potassium were applied as per the soil test based recommendation, that is, $38 \mathrm{~kg} \mathrm{ha}^{-1}$ of $\mathrm{P}_{2} \mathrm{O}_{5}$, $38 \mathrm{~kg} \mathrm{ha}^{-1}$ of $\mathrm{K}_{2} \mathrm{O}$. Zinc was applied of $\mathrm{ZnSO}_{4}$ at $25 \mathrm{~kg} \mathrm{ha}^{-1}$. The full dose of $\mathrm{P}$ and zinc and half the dose of potassium were applied as basal at the time of planting and the remaining half the dose of potassium was top dressed at the time of panicle initiation. Table 2 shows treatment details of the experiments. The biometric observations of plant height, number of tillers, number of productive tillers, panicle length, panicle weight, harvest index, grain and straw yield were recorded at harvest stage. The growth and yield attribute data collected were subjected to analysis of variance (ANOVA) as outlined by Gomez and Gomez (1984). Significant means were separated using critical difference at 5\% level. Statistical analysis was executed using IRRISTAT statistical software.

\section{Results and Discussion}

\section{Growth and yield attributes}

The height of plant significantly differed by the methods of cultivation, nitrogen managements and their interactions. LP recorded highest plant height among methods of cultivation and LCC 4 recorded the highest plant height among $\mathrm{N}$ management. The multiple regression analysis revealed that the plant height was determined by the DMP at 
critical stage of crop growth significantly to the tune of 47.2 per cent. Numbers of tillers were significantly influenced by methods of cultivation, nitrogen managements and their interactions. LP recorded highest number of tillers among methods of cultivation and LCC 5 recorded the highest number of tillers among $\mathrm{N}$ management (Table 3). Multiple regressions indicated that 82 per cent of variation in the number of tillers could be attributed to the DMP at different stages of crop growth. The number of productive tillers significantly altered by the methods of cultivation, nitrogen managements and their interactions. LP received highest number of productive tillers among methods of cultivation. The least number of productive tillers was observed in ICM method of cultivation. Among N managements, LCC 5 recorded the highest productive tillers and least number of productive tillers was in the control plot. The multiple regression analysis had further shown that 84.4 per cent of the variation in the number of productive tillers could be accounted for the DMP recorded at critical stages of the crop growth.

The length of panicle significantly differed by the methods of cultivation and nitrogen managements. RP registered higher panicle length followed by ICM and LP methods, which were comparable. $\mathrm{N}$ management strategies though resulted in significantly higher panicle length, they were comparable among themselves but superior to the control plots. The weight of the panicle was found to be unaffected by the various methods of cultivation, whereas application of $\mathrm{N}$ through LCC or by blanket recommendation had resulted in significantly higher panicle weight, though they were comparable. The interaction effect was significant, but did not follow any specific trend. The multiple regression analysis had further indicated that 37.40 per cent of the variation in the panicle weight could be explained by the available $\mathrm{N}$ status of the soil at critical crop growth stages. The highest harvest index was recorded in LP followed by RP. In ICM and SRI methods, HI was comparable (Table 3). The control plot recorded the least harvest index value. All the $\mathrm{N}$ management strategies were comparable but superior to control. Similar trend was observed in the interaction effect. Multiple regression analysis showed that the variation in harvest index explained by the DMP to the tune of 57.5 per cent. Similarly, 44.1 per cent of the variation in the harvest index could be explained by the available $\mathrm{N}$ status of soil at critical crop growth stages.

\section{Grain and straw yield}

The result revealed that among the different methods of rice cultivation, LP registered significantly higher grain yield (2. $53 \mathrm{t} \mathrm{ha}^{-1}$ ) followed by ICM, SRI and RP. The grain yield of SRI and ICM were comparable. Lowest yield of $2.15 \mathrm{t} \mathrm{ha}^{-1}$ was recorded in RP (Table 4). The yield increase in LP was 10.2 and $17.2 \%$ higher than SRI and RP respectively irrespective of $\mathrm{N}$ management strategies. In case of $\mathrm{N}$ management strategies, the highest grain yield of $2.66 \mathrm{tha}^{-}$ ${ }^{1}$ was recorded with LCC 4 which was 11.1 , 19.8, 26.4 and 40.7\% higher than blanket, SPAD 35, SPAD 37 and control respectively irrespective of methods of cultivation. Grain yield of LCC 5 was comparable with LCC 4. Blanket application was comparable with SPAD 35 which is again comparable with SPAD 37. Lowest yield was recorded in control where no nitrogen was applied. Interaction of methods of cultivation and nitrogen managements on grain yield was significant. Among all the treatment combinations, SRI with LCC 4 recorded the highest grain yield than other combinations. Application of $\mathrm{N}$ through LCC 4 recorded highest grain yield under SRI and LP methods of cultivations and their grain yields were on par. Similarly, LCC 5 registered highest grain 
yield in ICM and RP methods of cultivation and their grain yields were the same. In case of grain yield prediction with multiple regression, the growth and yield attributes such as plant height, number of tillers, productive tillers, panicle length, panicle weight, 1000 grain weight, per cent spikelet fertility, per cent spikelet sterility, harvest index, filled grains and unfilled grains were contributing 86.0 per cent.

The yield of straw was influenced by the methods of cultivation and $\mathrm{N}$ management strategies. It was observed that among methods of rice cultivation, ICM recorded significantly higher straw yield of $5.49 \mathrm{t} \mathrm{ha}^{-1}$ followed by SRI, LP and RP. The straw yield of SRI and ICM were comparable. Lowest yield of $4.07 \mathrm{t} \mathrm{ha}^{-1}$ was recorded in RP (Table 4). The straw yield of ICM was 28.4 and 34.6 $\%$ higher than LP and RP respectively. Among $\mathrm{N}$ management strategies, the highest straw yield of $5.88 \mathrm{t} \mathrm{ha}^{-1}$ was observed with LCC 5 which was $1.2,15.4,30.7,53.7$ and $59.2 \%$ higher over LCC 4, Blanket application, SPAD 35, SPAD 37 and control respectively. Interaction of methods of cultivation and nitrogen management strategies on straw yield was significant. Among all the treatment combinations, SRI with LCC recorded the highest straw yield than other treatment combinations. Application of $\mathrm{N}$ through LCC 5 recorded highest straw yield under SRI and RP methods of cultivations. LCC 4 under LP combinations registered higher straw yield. Blanket application of nitrogen under ICM combinations recorded the higher straw yield. Straw yield prediction with multiple regression, the growth and yield attributes such as plant height, number of tillers, productive tillers, panicle length, panicle weight, 1000 grain weight, per cent spikelet fertility, per cent spikelet sterility, harvest index, filled grains and unfilled grains were contributing 79.5 per cent.

\section{Growth and Yield Attributes}

Growth of plant is considered as basic criteria upon which final economic yield depends on. The various growth and yield attributes found higher in LP than SRI and ICM (Table 3). The trend was most pronounced for plant height, number of tillers and productive tillers and panicle length. The reason might be LP was able to produce more tillers due to higher population (66 plants $\mathrm{m}^{-2}$ ) against SRI (20 plants $\left.\mathrm{m}^{-2}\right)$, ICM (16 plants $\mathrm{m}^{-2}$ ) and RP (3033 plants $\mathrm{m}^{-2}$ ). The SRI and ICM methods could not produce more productive tillers due saline-sodic condition of soil.

Similarly, growth and yield attributes were found higher with LCC method of $\mathrm{N}$ management which is comparable with SPAD. The advantage of using either LCC or SPAD for monitoring leaf $\mathrm{N}$ content by real time measurement ensures $\mathrm{N}$ supply as per crop requirements with appropriate time with maximum $\mathrm{N}$ use efficiency. Similar results of higher growth and yield attributes by LCC method of $\mathrm{N}$ management was reported by Gunasekhar (2003) and Budhar (2005).

\section{Grain and Straw Yield}

LP recorded highest grain yield while SRI, ICM and RP were comparable (Table 4). This result of SRI quite against the results from Uphoff and Randriamiharisoa (2002), McHugh et al., (2002), Hossain et al., (2003), Uphoff (2003), and Sathayanarayana et al., (2004). The yield increase in SRI might be due to better phyllochron pattern (Moreau, 1987), reduced transplanting shock by early planting, better aeration through square planting, non-hypoxic soil condition by intermittent irrigation. Deep rooting provided by conducive soil conditions (Barison, 2002) supports for the expression of the plant's full genetic potential for tillering, shoot growth and grain filling (Uphoff, 2003). 
Table.1 Characterization of the experimental soil

\begin{tabular}{|c|c|}
\hline Properties & Values* \\
\hline \multicolumn{2}{|l|}{ Texture } \\
\hline Clay (per cent) & 21.65 \\
\hline Silt (per cent) & 6.75 \\
\hline Fine sand (per cent) & 58.75 \\
\hline Coarse sand (per cent) & 10.25 \\
\hline Textural class & Sandy clay loam \\
\hline Taxonomic unit & Fluventic Haplustept \\
\hline Apparent specific gravity $\left(\mathrm{Mg} \mathrm{m}^{-3}\right)$ & 1.33 \\
\hline Absolute specific gravity $\left(\mathrm{Mg} \mathrm{m}^{-3}\right)$ & 2.59 \\
\hline Pore space (per cent) & 48.06 \\
\hline $\begin{array}{l}\text { Electrical conductivity }\left(\mathrm{dS} \mathrm{m}^{-1}\right)(1: 1 \text { Soil water } \\
\text { suspension) }\end{array}$ & 4.64 \\
\hline pH (1: 2 Soil water suspension) & 7.85 \\
\hline Organic carbon $\left(\mathrm{g} \mathrm{Kg}^{-1}\right)$ & 0.54 \\
\hline Cation exchange capacity $\left(\mathrm{cmol}\left(\mathrm{p}^{+}\right) \mathrm{kg}^{-1}\right)$ & 24.45 \\
\hline Exchangeable Calcium $\left(\mathrm{cmol}\left(\mathrm{p}^{+}\right) \mathrm{kg}^{-1}\right)$ & 11.25 \\
\hline Exchangeable magnesium $\left(\mathrm{cmol}\left(\mathrm{p}^{+}\right) \mathrm{kg}^{-1}\right)$ & 8.16 \\
\hline Exchangeable sodium $\left(\mathrm{cmol}\left(\mathrm{p}^{+}\right) \mathrm{kg}^{-1}\right)$ & 4.15 \\
\hline Exchangeable potassium $\left(\mathrm{cmol}\left(\mathrm{p}^{+}\right) \mathrm{kg}^{-1}\right)$ & 0.31 \\
\hline SAR & 0.943 \\
\hline ESP (per cent) & 16.31 \\
\hline Total $\mathrm{N}$ (per cent) & 0.059 \\
\hline $\mathrm{KMnO}_{4}-\mathrm{N}\left(\mathrm{kg} \mathrm{ha}^{-1}\right)$ & 168.0 \\
\hline Olsen-P $\left(\mathrm{kg} \mathrm{ha}^{-1}\right)$ & 24.00 \\
\hline $\mathrm{NH}_{4} \mathrm{OAc}-\mathrm{K}\left(\mathrm{kg} \mathrm{ha}^{-1}\right)$ & 279.5 \\
\hline
\end{tabular}

\section{*Mean of three samples}


Table.2 Treatment details of field experiments

\begin{tabular}{|c|c|c|c|c|c|c|c|}
\hline \multicolumn{8}{|c|}{ Main plot treatments: Methods of rice cultivation } \\
\hline No. & Notation & Treatment & Nursery & Spacing (cm) & $\begin{array}{c}\text { Seedling } \\
\text { per hill }\end{array}$ & Irrigation & Weeding \\
\hline $\mathrm{M}_{1}$ & SRI & System of Rice Intensification & Dapog & $22.5 \times 22.5$ & 1 & \multirow[b]{2}{*}{$\begin{array}{l}\text { Alternate wetting } \\
\text { and drying }\end{array}$} & \multirow{2}{*}{$\begin{array}{l}\text { Cono weeding } \\
\text { thrice at } 10 \text { days } \\
\text { intervals }\end{array}$} \\
\hline $\mathrm{M}_{2}$ & ICM & Integrated Crop Management & $\begin{array}{l}\text { Modified } \\
\text { mat }\end{array}$ & $25 \times 25$ & 2 & & \\
\hline $\mathrm{M}_{3}$ & LP & Line Planting & Conventional & $15 \times 10$ & $2-3$ & $\begin{array}{l}2.5 \mathrm{~cm} \mathrm{up} \mathrm{to} \\
\text { tillering and } 5 \mathrm{~cm} \\
\text { thereafter }\end{array}$ & \multirow{2}{*}{ 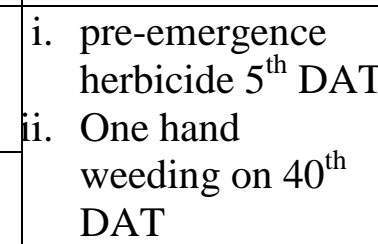 } \\
\hline $\mathrm{M}_{4}$ & $\mathrm{RP}$ & Random Planting & Conventional & Random spacing & $3-4$ & As per the need & \\
\hline \multicolumn{8}{|c|}{ Sub plot treatments: Nitrogen management } \\
\hline No. & Notation & Treatment & \multicolumn{5}{|c|}{$\mathbf{N}$ application } \\
\hline $\mathrm{N}_{1}$ & $\mathrm{C}$ & Control & \multicolumn{5}{|l|}{ No nitrogen } \\
\hline $\mathrm{N}_{2}$ & $\mathrm{BN}$ & Blanket $\mathrm{N}$ & \multicolumn{5}{|l|}{$120 \mathrm{~kg} \mathrm{ha}^{-1}$} \\
\hline $\mathrm{N}_{3}$ & LCC4 & $\begin{array}{l}\text { Leaf Colour Chart critical } \\
\text { value } 4\end{array}$ & \multicolumn{2}{|c|}{$* *$ if $\mathrm{LCC}$ value $<4$} & \multirow{2}{*}{\multicolumn{3}{|c|}{$\begin{array}{c}30 \mathrm{~kg} \mathrm{ha}^{-1} \\
\text { (From } 14^{\text {th }} \text { to } 70^{\text {th }} \text { DAT) } 9999\end{array}$}} \\
\hline $\mathrm{N}_{4}$ & LCC5 & $\begin{array}{l}\text { Leaf Colour Chart critical } \\
\text { value } 5\end{array}$ & \multicolumn{2}{|c|}{$* *$ if LCC value $<5$} & & & \\
\hline $\mathrm{N}_{5}$ & SPAD35 & *SPAD meter 35 & \multicolumn{2}{|c|}{$\begin{array}{l}* * \text { if SPAD meter critical value } \\
<35\end{array}$} & \multirow{2}{*}{\multicolumn{3}{|c|}{$\begin{array}{l}\text { i.Early to maximum tillering stage }-30 \mathrm{~kg} \mathrm{ha}^{-1} \\
\text { ii.Maximum tillering to panicle initiation }-45 \mathrm{~kg} \mathrm{ha}^{-1} \\
\text { iii.Panicle initiation to flowering stage }-30 \mathrm{~kg} \mathrm{ha}^{-1}\end{array}$}} \\
\hline $\mathrm{N}_{6}$ & SPAD37 & *SPAD meter 37 & \multicolumn{2}{|c|}{$\begin{array}{l}* * \text { if SPAD meter critical value } \\
<37\end{array}$} & & & \\
\hline
\end{tabular}

** Weekly observation from 14 DAT to 70 DAT *SPAD: Soil and Plant Analysis Department 
Table.3 Growth and yield parameters under different methods of cultivation and $\mathrm{N}$ management strategies

\begin{tabular}{|c|c|c|c|c|c|c|c|c|c|c|c|c|c|c|c|}
\hline \multirow[b]{2}{*}{$\mathbf{N}$} & \multicolumn{5}{|c|}{ Plant Height $(\mathrm{cm}) *$} & \multicolumn{5}{|c|}{ No. of tillers* } & \multicolumn{5}{|c|}{ No. of productive tillers* } \\
\hline & SRI & ICM & $\mathbf{L P}$ & $\mathbf{R P}$ & Mean & SRI & ICM & $\mathbf{L P}$ & $\mathbf{R P}$ & Mean & SRI & ICM & LP & $\mathbf{R P}$ & Mean \\
\hline Control & 59.90 & 62.10 & 66.60 & 61.80 & 62.60 & 189.0 & 190.4 & 445.4 & 322.0 & 286.7 & 115.9 & 113.6 & 319.9 & 202.0 & 187.9 \\
\hline Blanket & 65.00 & 65.30 & 76.80 & 71.90 & 70.50 & 435.8 & 305.6 & 593.3 & 295.0 & 407.4 & 288.4 & 216.0 & 426.6 & 323.2 & 313.5 \\
\hline LCC 4 & 71.40 & 65.85 & 76.80 & 72.50 & 71.64 & 421.9 & 335.2 & 660.0 & 310.0 & 431.8 & 301.5 & 232.0 & 446.6 & 270.9 & 312.7 \\
\hline LCC 5 & 66.70 & 71.10 & 70.30 & 70.00 & 69.53 & 406.8 & 352.0 & 726.7 & 395.0 & 470.1 & 273.1 & 246.4 & 486.6 & 263.4 & 317.4 \\
\hline SPAD 35 & 69.90 & 67.80 & 65.20 & 71.00 & 68.47 & 335.8 & 300.0 & 603.3 & 369.0 & 402.2 & 244.9 & 235.6 & 443.3 & 192.0 & 279.0 \\
\hline SPAD 37 & 56.30 & 71.50 & 70.80 & 62.00 & 65.40 & 405.5 & 328.8 & 686.2 & 416.5 & 459.2 & 281.0 & 228.8 & 442.5 & 282.0 & 308.6 \\
\hline \multirow[t]{2}{*}{ Mean } & 64.87 & 67.28 & 71.75 & 68.20 & & 365.8 & 302.1 & 619.1 & 351.3 & & 250.8 & 212.1 & 427.6 & 255.0 & \\
\hline & $\mathbf{M}$ & $\mathbf{N}$ & $\mathbf{N x M}$ & $\mathbf{M x N}$ & & $\mathbf{M}$ & $\mathbf{N}$ & $\mathbf{N x M}$ & $\mathbf{M x N}$ & & $\mathbf{M}$ & $\mathbf{N}$ & $\mathbf{N x M}$ & $\mathbf{M x N}$ & $\mathbf{M}$ \\
\hline S. Ed & 0.83 & 1.86 & 3.37 & 3.71 & & 24.7 & 18.4 & 43.9 & 36.7 & & 10.4 & 11.2 & 23.1 & 22.4 & 10.4 \\
\hline \multirow[t]{2}{*}{ C.D $(P=0.05)$} & 2.64 & 3.87 & 7.37 & 7.74 & & 78.5 & 38.3 & 114.3 & 76.6 & & 33.0 & 23.4 & 56.0 & 46.7 & 33.0 \\
\hline & \multicolumn{5}{|c|}{ Panicle length $(\mathrm{cm})^{*}$} & \multicolumn{5}{|c|}{ Panicle weight $(\mathrm{g})^{*}$} & \multicolumn{5}{|c|}{ Harvest Index (\%) } \\
\hline Control & 16.07 & 16.28 & 16.51 & 16.93 & 16.5 & 0.945 & 0.947 & 1.008 & 1.086 & 0.996 & 26.10 & 26.40 & 34.90 & 30.03 & 29.35 \\
\hline Blanket & 17.88 & 18.88 & 21.03 & 20.26 & 19.51 & 1.135 & 1.064 & 1.325 & 1.353 & 1.219 & 27.62 & 31.55 & 40.32 & 33.10 & 33.14 \\
\hline LCC 4 & 18.00 & 19.04 & 19.54 & 21.47 & 19.51 & 1.307 & 1.159 & 1.180 & 1.407 & 1.263 & 33.02 & 29.29 & 33.85 & 34.28 & 32.61 \\
\hline LCC 5 & 18.36 & 21.75 & 20.11 & 21.78 & 20.50 & 1.392 & 1.473 & 1.043 & 1.182 & 1.272 & 29.07 & 33.27 & 35.48 & 37.74 & 33.89 \\
\hline SPAD 35 & 17.42 & 20.02 & 18.18 & 20.72 & 19.09 & 1.125 & 1.142 & 0.994 & 1.122 & 1.096 & 29.99 & 29.46 & 36.55 & 33.24 & 32.31 \\
\hline SPAD 37 & 17.60 & 19.33 & 18.19 & 20.27 & 18.85 & 1.176 & 1.234 & 1.020 & 1.000 & 1.107 & 32.94 & 32.23 & 39.37 & 26.24 & 32.69 \\
\hline \multirow[t]{2}{*}{ Mean } & 17.56 & 19.22 & 18.93 & 20.24 & & 1.180 & 1.170 & 1.095 & 1.191 & & 29.79 & 30.36 & 36.74 & 32.44 & - \\
\hline & $\mathbf{M}$ & $\mathbf{N}$ & NxM & $\mathbf{M x N}$ & & $\mathbf{M}$ & $\mathbf{N}$ & NxM & $\mathbf{M x N}$ & & $\mathbf{M}$ & $\mathbf{N}$ & $\mathbf{N x M}$ & $\mathbf{M x N}$ & \\
\hline S. Ed & 0.31 & 0.52 & 0.98 & 1.05 & & 0.035 & 0.058 & 0.109 & 0.115 & & 0.556 & 1.325 & 2.394 & 2.649 & \\
\hline C.D $(P=0.05)$ & 0.98 & 1.09 & NS & NS & & NS & 0.120 & 0.246 & 0.240 & & 1.77 & 2.76 & 5.21 & 5.53 & \\
\hline
\end{tabular}

*Mean of ten samples, NS, Non significant 
Table.4 Yield of rice crop under different methods of cultivation and $\mathrm{N}$ management strategies

\begin{tabular}{|c|c|c|c|c|c|c|c|c|c|c|}
\hline \multirow[t]{2}{*}{ Treatments } & \multicolumn{5}{|c|}{ Grain yield $\left(\mathrm{kg} \mathrm{ha}^{-1}\right)$} & \multicolumn{5}{|c|}{ Straw yield $\left(\mathrm{kg} \mathrm{ha}^{-1}\right)$} \\
\hline & SRI & ICM & LP & $\mathbf{R P}$ & Mean & SRI & ICM & LP & $\mathbf{R P}$ & Mean \\
\hline Control & 1640 & 1904 & 2170 & 1839 & 1888 & 3344 & 4594 & 3532 & 3312 & 3696 \\
\hline Blanket & 2091 & 2518 & 2712 & 2248 & 2392 & 5657 & 6635 & 3937 & 4156 & 5096 \\
\hline LCC 4 & 3119 & 2189 & 2966 & 2353 & 2657 & 6783 & 6531 & 5719 & 4219 & 5813 \\
\hline LCC 5 & 2229 & 2976 & 2535 & 2675 & 2604 & 6850 & 6472 & 5300 & 4909 & 5883 \\
\hline SPAD 35 & 2440 & 2056 & 2288 & 2137 & 2230 & 5750 & 4375 & 3563 & 4313 & 4500 \\
\hline SPAD 37 & 2107 & 2110 & 2502 & 1690 & 2102 & 3774 & 4344 & 3625 & 3563 & 3827 \\
\hline Mean & 2271 & 2292 & 2529 & 2157 & & 5360 & 5492 & 4279 & 4079 & \\
\hline & $\mathbf{M}$ & $\mathbf{N}$ & $\mathbf{N x M}$ & $\mathbf{M x N}$ & & $\mathbf{M}$ & $\mathbf{N}$ & $\mathbf{N x M}$ & $\mathbf{M x N}$ & \\
\hline S. Ed & 66.2 & 96.5 & 185.8 & 193.0 & & 65.6 & 137.7 & 251.3 & 275.4 & \\
\hline $\begin{array}{l}\text { C.D } \\
(P=0.05)\end{array}$ & 211 & 201 & 426 & 403 & & 205 & 287 & 552 & 575 & \\
\hline
\end{tabular}

In the present investigation, the major constraints which were faced in the SRI method of cultivation is that when the seedlings were grown in the dapog nursery, the germination and establishment was relatively slow due to salt raise up by capillarity causing salt injury to the young seedlings. In the main field also the young seedlings were unable to revive from the transplantation shock for a week due to minimum water level maintained to avoid floating of seedlings which had resulted in salt injury. It was also seen that the number of tillers, number of productive tillers and harvest index were significantly lower than the LP method in the present study obviously due to the above said reasons. The above inference is in line with Krupakar Reddy et al, (2004), who reported SRI and conventional planting are comparable. It was also seen from the results of Andriankaja (2001) that the SRI method was better expressed in clay soil than in loamy soil. It was even reported by Uphoff (2003), while summarizing the results of SRI trials from various countries, there are certain places where SRI recorded lower yields than conventional methods.

The ICM was also found to be inferior to LP and comparable with SRI and RP methods.
As discussed in the case of SRI, the ICM did not result in higher grain yield due to the saline-sodic condition of soil. Among the N management strategies, the LCC method of $\mathrm{N}$ management recorded higher grain yield followed by the blanket recommendation and SPAD methods (Singh et al., 2008). It was further revealed that there were no marked difference between LCC 4 and 5 leading to the conclusion that LCC 4 itself is sufficient to meet the crop requirements. Similar results of $\mathrm{N}$ management were reported by Porpavai et al., (2002), Budhar and Tamilselvan (2003), Budhar (2005) and Witt et al., (2005). It was further seen that SPAD method did not result in higher yield as compared to the LCC method, but was comparable to the blanket recommendation. In case of the straw yield ICM and SRI had recorded higher straw yield as compared to LP and RP, which were comparable possibly due to poor translocation of photosynthates from source to sink in SRI and ICM. However, increased straw yield in SRI has been reported by Sathayanarayana et al., (2004) and that of ICM by Balasubarmanian et al., (2004). Higher straw yield was recorded in LCC N management, also reported by Coumaravel (2002), Gunasekhar (2003) and Budhar (2005). 
In conclusion, the present investigation concludes that line planting method of cultivation with nitrogen management through LCC 4 performed better due to more number of plant population which resulted in more productive tillers. Plant population in line planting was highest among methods of cultivation. Among $\mathrm{N}$ management strategies LCC 4 \& 5 performed better because of need based application of nitrogen as and when it required, which reduced the $\mathrm{N}$ loss in saline sodic soil and increased the $\mathrm{N}$ use efficiency. Poor performance in SRI and ICM due to optimum plant population in these methods of cultivation become insufficient to produce required number of productive tillers. Moreover, the saline-sodic condition of soil could not allow the tillers to become productive tillers. Hence, line planting is better than SRI, ICM and random planting when soil quality is poor. Application of nitrogen based on LCC 4 is better than LCC 5, blanket recommendation, SPAD 35 and SPAD 37.

\section{References}

Andriankaja A (2001). Evidence on the opportunities for development of rice production with the adoption of the System of Rice Intensification, and evaluation of biological nitrogen fixation. Thesis for the Department of Agriculture (Agronomy), Higher School for Agricultural Sciences (ESSA), University of Antananarivo.

Babu M, Nagarajan R, Ramanathan SP (2000). Optimizing chlorophyll meter threshold values for different seasons and varieties in irrigated lowland rice systems of the Cauvery Delta Zone, Tamil Nadu, India. Int. Rice Res. Newsletter. 25: 27-28.

Balasubramanian V, Rajendran R, Ravi V, Chellaiah N, Castro E, Chandrasekeran B, Jayaraj T, Ramanathan S (2004).
Integrated crop management and modified mat nursery for enhancing yield and profitability in Transplanted rice systems of Asia. Paper presented at the $39^{\text {th }}$ All India Rice Research Group Meeting, IARI, New Delhi, India. 12-14 Apr. 2004. In Special Lectures-2004, Directorate of Rice Research, Hyderabad -500 030. India.

Barison J (2002). Nutrient-use efficiency and nutrient uptake in conventional and intensive (SRI) rice cultivation systems in Madagascar. Thesis of Master degree, Department of Crop and Soil Science, Cornell University, Ithaca, NY.

Budhar MN, Tamilselvan N (2003). Leaf colour chart based $\mathrm{N}$ management in wet seeded rice. Int. Rice Res. Newsletter. 28: 63-64.

Budhur MN (2005). Leaf colour chart based nitrogen management in direct seeded rice puddle rice. Fert. News. (50): 4144.

Coumaravel K (2002). Studies on the effect of different nitrogen management tools on yield and uptake of nutrients by rice. M.Sc. (Ag.) Thesis, submitted to Tamil Nadu Agric. Univ., Coimbatore, India.

Duraisamy K, Kathiresan G, Narayanaswamy MR (2001). Rice cultivation in Tamil Nadu, First edition, Golden net Publisher, Tiruchirappalli, Tamil Nadu, India.

Furuya S (1987). Growth diagnosis of rice plants by means of leaf colour. Jap. Agric. Res. Quar., 20: 147-153.

Gomez KA, Gomez K (1984). Statistical Procedure for Agricultural Research. John-Wiley and Sons Inc., New York, pp.680.

Gunasekhar N (2003). Standardization of leaf colour chart (LCC) based nitrogen management in direct wet (drum) seeded rice. M.Sc. (Ag.) Thesis, Tamil Nadu Agric. Univ., Coimbatore, India.

Hossain MZ, Hossian SMA, Anwar MP, 
Sarker MRA, Mamum AA (2003). Performance of BRRI Dhan 32 in SRI and Conventional methods and their technology mixes. Pak. J. Agron. 2: 195-200.

Kabir H, Uphoff N (2007). Results of disseminating the System of Rice Intensification with Farmer Field School methods in Northern Myanmar. Exp. Agric. 43:4

Krupakar Reddy G, Yakadari M, Shaik Mohammed, Chandrasekhar Rao P (2004). SRI methodology in rice - a farmer \& ecofriendly approach in semi arid tropics. In: Extended summaries of contributed papers International symposium on rice from green revolution to gene revolution. DRR, Hyderabad, AP. India. pp 283-284.

Laulanié H (1993). Le système de riziculture intensive malgache. Tropicultura 13(1):110-114

McHugh OV, Steenhuis TS, Barison J, Fernandoes ECM, Uphoff NT (2002). Farmer implementation of alternate wetdry and nonflooded irrigation practices in the System of Rice Intensification (SRI). In: Bouman BAM, Hengsdijk H. Hardy B.Birdraban PS, Tuong TP, Ladha JK, (Ed) water wise rice production. Proc. of the International Workshop on Water wise Rice production 8-11 April 2002. Los Banos, Phillippines. Los Banos (Phillippines): IRRI. pp 89-102.

Moreau Didier (1987). Analuse de lEElabouration des Rendimentsdu Riz. Paris: GRET.

Namara R, Bossio D, Weligamage P, Herath I (2008) The practice and effects of the System of Rice Intensification (SRI) in Sri Lanka. Qtly. J. Intl. Agric. (47):5-23.

Porpavai S, Muralikrishnasamy S, Nadanasabapathy T, Jayapaul, Balasubramanian $\quad$ V (2002).
Standardizing critical leaf colour chart values for transplanted rice in Cauvery new delta. Agric. Sci. Digest. 22 (3): 207-208.

Randhawa NS, Velayutham M (1989). In: Proceeding of a colloquium on soil fertility and fertilizer management in semi arid tropical India (Edt.) Christianson, $\mathrm{C}$ and Bruce, R.D.). International fertilizer development center, Muscle Shoals, ALA, USA

Sathayanarayana PV, Srinivas T, Satyanayana A (2004). On farm evaluation of the System of Rice Intensification (SRI) in Andhra Pradesh, India. In: Proc. of world Rice Research conference 2004, Tsukuba International Congress Center, Tsukuba, Japan. 5-7 Nov.2004. 382.

Senthilkumar K, Bindraban PS, Thiyagarajan TM, Ridder N, Giller KE (2008). Modified rice cultivation in Tamil Nadu, India: Yield gains and farmers' (lack of) acceptance. Agric. Syst. (98):82-94

Shobarani N, Prasad GSV, Prasad ASR, Sailaja B, Muthuraman P, Numeera S, Viraktamath BC (2010). Rice Almanac-India. DRR Technical Bulletin No 5, Directorate of Rice Research, Rajendranagar, Hyderabad.

Singh RD, Sikka AK, Shivani, Rajan K (2008). Effect of irrigation and nitrogen on yield, water use efficiency and nutrient balance in rice (Oryza sativa)Based cropping system. Indian Journal of Agricultural Sciences 78: 21-26.

Thiyagarajan TM (2007). SRI in Tami Nadu: Current Scenario. In: SRI in India (2007) Second National Symposium on System of Rice Intensification (SRI) in India - Progress and Prospects. Papers and Extended Summaries, 3-5th October, Agartala, Tripura, India, 136138.

Uphoff N, Randriamiharisoa R (2002). Reducing water use in irrigated rice 
crop with the Madagascar system of rice intensification (SRI). In: Bouman BAM, Hengsdijk H. Hardy B.Birdraban PS, Tuong TP, Ladha JK, (ed.) water wise rice production. Proceedings of the International Workshop on Water wise Rice production 8-11 April 2002. Los Banos, Phillippines. Los Banos (Phillippines): IRRI. 89-102.

Uphoff N (2002). Changes and Evolution in SRI methods. In: Proceedings of International conference on the Assessments of the SRI Sanya, China. 1-4 April 2002. Cornell University,
Ithaca, New York, 8-14.

Uphoff N (2003). Possible explanation for the productivity gains achieved with the System of Rice Intensification (SRI). In Proc. of International Symposium on: Transitions in Agriculture for Enhancing Water Productivity held at AC and RI, Killikulam, India, Sep. 2325. 2003.

Witt C, Pasuquin JMCA, Mutters B, Buresh RJ (2005). New leaf colour chart for effective nitrogen management in rice. Better Crops. 80: 36-39.

\section{How to cite this article:}

Dinesh, D., A. Baskar and Rajan, K. 2017. Effect of Cultivation Methods and Nitrogen Management Strategies on Growth and Yield of Rice (Oryza sativa L.) Grown in Coastal Alluvial Soils of Southern India. Int.J.Curr.Microbiol.App.Sci. 6(3): 2176-2187. doi: https://doi.org/10.20546/ijcmas.2017.603.248 